\title{
The Establishment of Perceptions and Healthy Living Attitudes for Children Through Modern Fairytale Based on Covid-19
}

\author{
Asteria, P. V..$^{1 *}$ Yulianto, B. ${ }^{1}$, Suyatno ${ }^{1}$, Sodiq,,${ }^{1}{ }^{1}$, Yohanes, B. ${ }^{1}$ \\ ${ }^{1}$ Department of Indonesian Language and Literature, Universitas Negeri Surabaya, Surabaya \\ *Corresponding author. Email: primaasteria@unesa.ac.id
}

\begin{abstract}
This study presents a covid-19 fairytale with modern stories related to everyday experiences equipped with 2D animated videos. Animated videos and fairy tale books are arranged based on the characteristics of children as research subjects. The designated aim are perceptions and healthy attitudes in order to control the impact of the Covid-19 Virus. The fairytale is complemented by a puzzle evaluation form to conduct a pleasant learning atmosphere. Therefore, the aim of this study is to form perceptions and healthy attitudes for children based on the control of the Covid-19 outbreak. The research method used Research and Development (R\&D). The development model use the Borg \& Gall development procedure which is tailored to the needs and context of this research, namely (1) Research and data collection stage, (2) Planning stage, (3) Product Development stage, (4) Trial Test and Expert Validity stage, and (5) Product Revision stage. The results of the trial questionnaire showed that children were able to understand and practice the habit of washing hands with soap, wearing masks, and maintaining distance before and after interacting with other people and the results of expert validation received a very good assessment with an average value of 91.1.
\end{abstract}

Keywords: Perceptions, Attitudes, Children, Fairytale, Controlling Covid-19

\section{INTRODUCTION}

The covid-19 virus pandemic has spread to various regions of the world. Research and medical action are carried out to deal with the Covid-19 or corona virus outbreak, but no one has been able to find a cure. The final defense against the corona virus is the antibody system in the human body. However, the effectiveness of the antibody system is relative. In toddlers, the antibody system is not fully formed. In older people, the immune system is getting weaker, while in sick people, its effectiveness decreases [1]. Other factors that reduce the immune system are stress or depression, malnutrition, lack of exercise, smoking, and alcohol consumption $[2,3]$. Therefore, people who are suffering from illness, the elderly, and children tend to be at high risk if they exposed to the corona virus.

Data shows that the child mortality rate due to the covid-19 virus in Indonesia ranks first among Southeast Asian countries. The Ministry of Health said that as of Saturday, May 30, 2020, there were 1,851 cases of Covid-19 in children aged less than 18 years. Covid-19 exposure cases to children occurred in almost all regions of Indonesia, including in the DKI Jakarta area with 333 cases, East Java with 306 cases, South Sumatra with 181 cases, South Sulawesi with 151 cases, Central Java with 100 cases, and West Nusa Tenggara has reached 84 cases [4]. In fact, based on data on May 13, 2020, the number of children who experienced Covid-19 infection had just recorded 584 cases with 14 children reportedly dying. The data on August 2, 2020 shows that the number of confirmed cases of Covid-19 has reached 9,390 cases in children aged 0-18 years. The high rate of spread and the number of deaths in children in Indonesia is due to the delay in diagnosing Covid-19 so that pediatric patients are in a severe condition when they come to the hospital [5].

This graph shows that the spread of the Covid-19 virus among children has increased significantly. The chart trend in mid-March was still slightly sloping, but from April to August it showed an increasing trend. This shows that efforts to prevent the spread of the Covid-19 virus in children have not been effectively implemented. If all levels of society have not moved to control the spread of Covid-19, more and more children are threatened with exposure to the Covid-19 virus. 


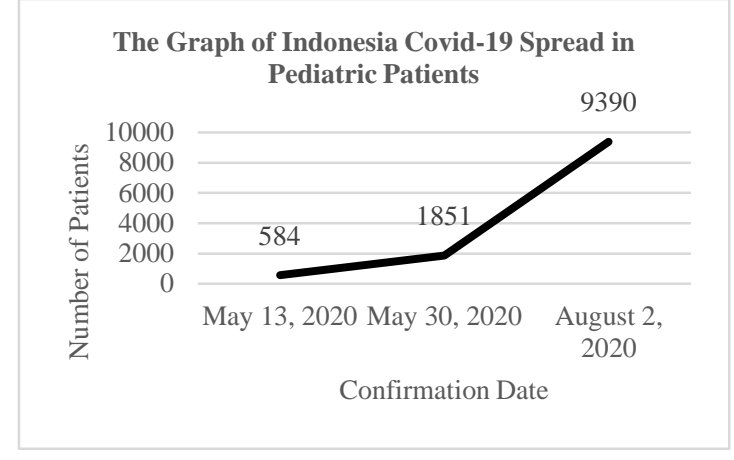

Source: compiled from various sources

Figure 1 Graph of The Distribution Rate of Pediatric Patients with Covid-19

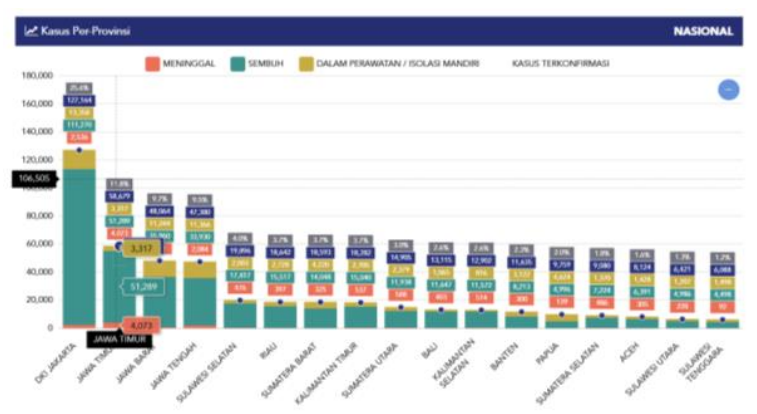

Source: https://covid19.go.id/peta-sebaran [6]

Figure 2 The Graph of Indonesia Covid-19 Patients

The health risk to the impact of covid-19 transmission on Indonesian children is enormous. In fact, the mortality rate for Indonesian children during this pandemic is quite high compared to other countries. The causative factors consist of slowness in the detection process, delays in medical treatment, and low examination accuracy [7]. In addition, the number of children in Indonesia who have comorbidities is very high. Most of the population of children in Indonesia have comorbidities, such as malnutrition, anemia, stress, diarrhea, and pneumonia. Even though the symptoms shown in Covid-19 are almost the same as the symptoms that arise due to these comorbidities so that early diagnosis errors often occur. This is exacerbated by preventive efforts from the upstream, namely preventive efforts that do not work in the community. The risk of case transmission to children is getting higher with the large number of people who do not implement health protocols properly and orderly. This condition is increasingly dangerous in the absence of supervision of children's activities. Many children play and do activities outside the home without wearing the correct mask.

Before a vaccine found, preventive measures are the most effective way to fight the corona virus [8]. The \#physicaldistancing, \#workfromhome, \#learnfromhome, are preventive measures campaigned by the government. As a result, offices, schools and various places where people gather are closed. The goal is to limit the level of meeting people so that transmission of the corona virus can be reduced. However, the government's appeal to change culture, daily habits, and public awareness of the dangers from the corona virus is still being ignored. Still common adults hanging out together and children having fun playing with their friends as usual. Therefore, all parties must be involved in educating the community in their environment.

The events above show that education about the corona virus is also needed by school-age children. School closings did not not stop the spread of the corona virus in the community due to the lack of self-awareness of students and parents. This understanding needs to be instilled in children and parents. However, education aimed at children must be tailored to the character, abilities and needs of the child. This is in accordance with the pedagogical principle of the concept of constructivism where learning is carried out independently at home (home learning) and supervision from the teacher is carried out online. The relevant constructivism model implementated to the independent home learning is constructive, builds critical and ethical mindsets, sharpens psychology and social skills based on expectations and regulations [9].

Elementary students are increasingly familiar with technology. They have high enthusiasm in enjoying audiovisual content, especially through the use of gadgets and social media. The tendency of learning styles is also influenced by attitudes, habits, and technological developments [10]. Visual, Auditory, and Kinesthetic (VAK) based learning models are able to increase the acceptance of knowledge and knowledge transfer to students. Learning focuses on direct experiences that are fun. Learning is carried out by training and developing the potential of students, so that the use of the VAK learning model provides opportunities for students to learn directly using their learning styles to achieve effective understanding and learning [11].

Based on the explanation above, the researcher took the research with the theme " The Establishment of Perceptions and Healthy Living Attitudes for Children through Modern Fairytale based on Covid-19". This study presents a covid-19 fairy tale with modern stories related to everyday experiences equipped with $2 \mathrm{D}$ animated videos. Animated videos and fairy tale books are arranged based on the characteristics of children as research subjects. The use of fairy tale media is very effective in the framework of forming characters, attitudes, and actions in early childhood [12]. The aim is to form perceptions and healthy attitudes in order to control the impact of the Covid-19 Virus. The fairy tale is complemented by an evaluation in the form of a puzzle to condition a pleasant learning atmosphere. Therefore, the aim of this study is to form perceptions and healthy attitudes for children based on the control of the Covid19 outbreak. 


\subsection{Covid-19 Control}

The corona virus can cause various symptoms in people with it. The symptoms that appear depend on the type of corona virus that attacks, and how serious the infection is. Here are some mild symptoms of the corona virus: runny nose, headache, cough, sore throat, fever, feeling unwell. What needs to be emphasized is that some coronaviruses can cause severe symptoms. The infection can turn into bronchitis and pneumonia (caused by COVID-19), resulting in symptoms such as: fever which may be quite high if the patient has pneumonia, cough with mucus, shortness of breath, chest pain or shortness of breath and coughing. The infection can get worse if it affects certain groups of individuals. For example, people with heart or lung disease, people with weakened immune systems, infants, and the elderly.

In order to diagnose corona virus infection, the doctor will start with a history or medical interview. Here the doctor will ask about the symptoms or complaints experienced by the patient. In addition, the doctor will also perform a physical examination and blood tests to help make a diagnosis. The doctor may also perform a sputum test, take a sample from the throat, or other breathing specimen. For cases of suspected novel coronavirus infection, the doctor will perform throat swabs, DPL, liver function, kidney function, and PCT / CRP [13].

\subsection{Child Education Characteristics}

When planning the learning activity, the ability, skills and carefulness of learning designers are needed to analyze certain situations and circumstances of their students. Each student and class group has different characters and abilities, so that the same treatment of all students and class groups will actually result in a less than optimal learning process. Therefore, one of the important stages in the planning process of learning activity is analyzing student characteristics. Understanding of student characteristics greatly influences the achievement of the learning process, especially in onlinebased learning [14]. This must be taken into account because the impact of the spread of covid-19 forces the government to carried out online learning.

The thought patterns, perceptions and ways of overcoming problems that are owned by children at primary school age are very different. In childhood the tendency to imitate someone who is idolized is very large. Childhood is a time of play and learning. Heavy burdens on schools and almost the same learning conditions sometimes reduce children's rights to play, causing children to tend to be lazy and bored when learning in class. Therefore, the implementation of an analysis of students' initial abilities that includes the characteristics of age, physical, psychomotor, academic, and attitude is needed.

\subsection{Fairytale}

Children's story books are very useful for improving student literacy. Children's story books, one of which is fairy tales, can train children's creativity through children's imagination on the story components contained in them. Literature is present to readers, first of all, to provide entertainment, fun entertainment. Therefore, the children's story books that are presented need to be adapted to the characters of the children. Furthermore, "children's literature is literature emotionally, psychology can be responded to and understood by children, and generally departs from concrete facts and is easy to understand and imagine" [15]. It can be interpreted that fairy tales as one of the children's reading books must contain the child's own culture or environment because it is in accordance with children's knowledge which must be clear and concrete.

"Books can play an important role in children's lives, but the role of these books depends on parents and teachers guiding them" [16]. To achieve this important role, teachers as parents of students in schools need a strategy to introduce books to their students. Story books are the right choice because story books will be able to attract students' interest in reading more than reading textbooks or reference books in which there are only learning material. Children in elementary school age really like things or readings that are fun to read, one of which is fairy tales or imaginative reading. According to Bassett, Jacka, and Logan, elementary school age students have a curiosity about the natural surroundings, like to play and enjoy trying new things. Thus, they need an interesting way to introduce or add knowledge that is useful for their daily lives [17]. The story book needed is an entertaining book and does not contain complicated materials with the aim of students learning as well as getting entertainment from reading results. In connection with the phenomenon of the Covid-19 outbreak that has penetrated the entire world since the end of 2019, students need to understand Covid-19 or Corona in a simple way so that students can take the right attitude during this

\subsection{State of the Art}

Research on the Development of a Puzzle-Based Covid-19 Story Book as an Effort to Control the Covid19 Outbreak is original research. As a comparison, here are some previous studies that have similarities and differences in terms of themes, subjects, methods, media, and research instruments. Previous research entitled Constructivism-Based Learning Using Animated Media with the TPCK Framework and Learning Styles on Student Learning Achievement [18]. This research uses the actual experimental method. The population of this study were students of class XI SMK 1 Dedai. The data collection techniques used in this study were the test 
method to measure learning achievement, a questionnaire to measure learning styles, and an observation sheet to measure student learning outcomes in affective and psychomotor aspects. The results showed; 1) the learning style profile of the XI grade students of SMK 1 Dedai; 2) there is an effect of constructivism-based learning using animation media on student achievement, (3) there is no influence of learning styles on student achievement, (4) there is an effect of using animation media and learning styles on student achievement.

The next research entitled the Use of Audio Visual Media in Learning to Listen to Fairy Tales in the Digital Age [19]. Research on the use of audio-visual media in learning to listen to fairy tales was carried out at SDN 6 Singaparna. The research method used is descriptive qualitative method. Students' enthusiasm in learning to listen to fairy tales using audio-visual media is better than learning to listen to fairy tales read directly by the teacher. This can be seen from the average ability of students to listen to fairy tales. The average storytelling ability of students after using audio-visual media was 84.53 , while the average ability to listen to fairy tales before was only 67.20. In addition to increasing the students' ability to listen to fairy tales, the use of audiovisual media also makes students more active in the learning process. This can be seen when the teacher asks several questions when the fairy tale has been played, most students respond well to the questions given by the teacher.

Subsequent research entitled Application of Interactive Multimedia Applications for Reading Learning Methods of Syllables and Digital Media for Character Tales [20]. The method of developing multimedia application tools uses the Luther method, which is a process used to assist software developers in forming a model of the software that must be made. In making this application, using strength in the form of media application assistance for drawing, animation, and authoring consists of Adobe Photoshop, Adobe Director, Adobe Flash, and Sony Vegas sound applications. Computer-assisted interactive multimedia learners can help students learn and understand how to read the syllable method with the addition of digital media character fairy tales. One of the interactive multimedia has been created to help children in learning to read the syllable method. The multimedia program is made by combining several animations, pictures, films, and games that are connected to the material for reading the syllable method. Virtual images are used for children to understand and learn from material by comparing with real things in our lives. This interactive learning multimedia is packaged in the form of a mobile application, which can be accessed on the Google Playstore. An interactive multimedia program made for children in the Anakku Sayang Reading Class.
The latest research is entitled Windows Communication Foundation for Fairy Tale Audiobooks for Blind Children [21]. This study aims to design and build a Windows Communication Foundation for the fairy tale audiobook application so that children with visual impairments can benefit from it. This research was conducted in 3 stages, namely system analysis, system design, and system implementation and testing. The result of this research is Windows Communication Foundation software with 3 services, namely services for adding fairy tale audio data, services for selecting and playing fairy tale audio, and services for viewing fairy tale audio lists. Based on the results of testing on the Windows Communication Foundation, all of these services are functioning properly.

The following is a comparison table with previous research, it can be seen that this study has differences in terms of: research themes, learning media, learning models, and evaluation instruments. While the equation is only found at the educational level of the research subject. Therefore, this research can be stated as original and different from previous studies.

Table 1. Table of State of the Art

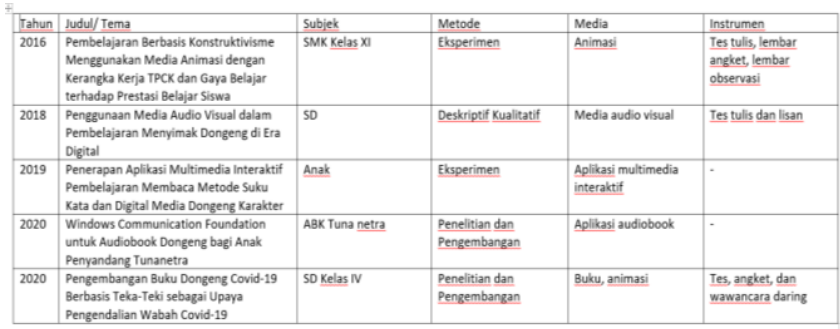

\section{METHOD}

The following is a research procedure that is applied based on the stages of the activities carried out [22].

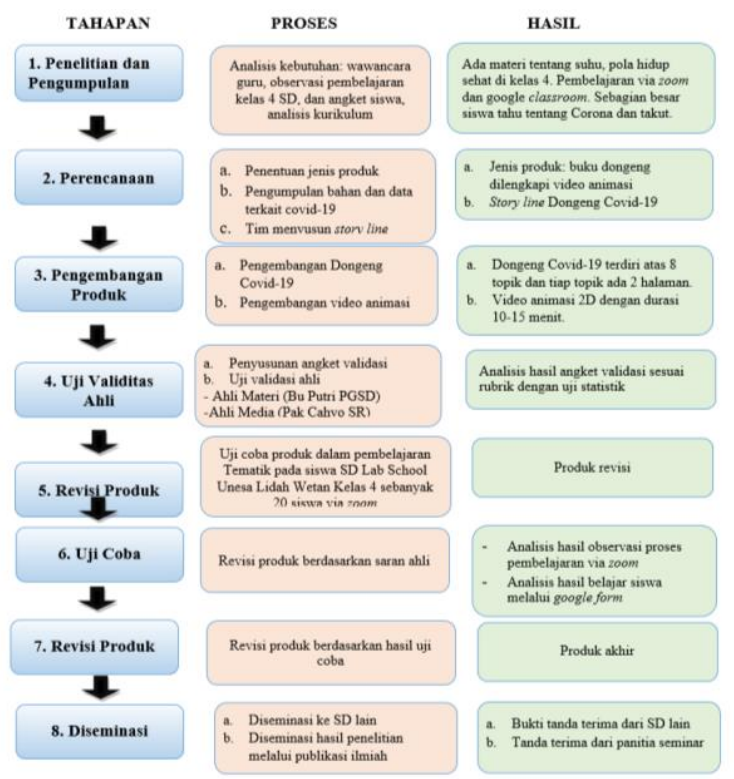

Figure 3 Research Procedure 


\section{RESULT AND DISCUSSION}

\subsection{Storyline of Fairytale}

Fairy tales and animations about Covid-19 cover 7 (seven) topics or aspects, namely understanding of covid19, efforts to prevent covid-19 transmission, transmission of covid-19, clinical symptoms of covid-19, covid-19 tests, independent isolation, and hospital care. The topic selection was based on the importance of understanding the characteristics of Covid-19. The story setting for each topic is based on daily events that are often encountered or experienced by children. The background of the story on the first topic is watching news on television, the background for the second topic is children playing with their friends, the background for the third topic is family shopping together, the background for the fourth topic is for the sick father, the background for the fifth topic is for checking in the hospital, the background for the topic sixth is hospital care, and the seventh topic is home selfisolation.

Dialogue in each setting is based on the consideration of the research target, namely elementary school age children, so that the conversation consists of simple sentences and the dialogue from each character consists of a maximum of 2 sentences for each stage of the dialogue. Meanwhile, puzzles that are structured as an evaluation of understanding begin with explanatory sentences to help limit the understanding context of the research target The fairy tale storyline and series of scenes from the fairy tale animation are depicted in the following figure.

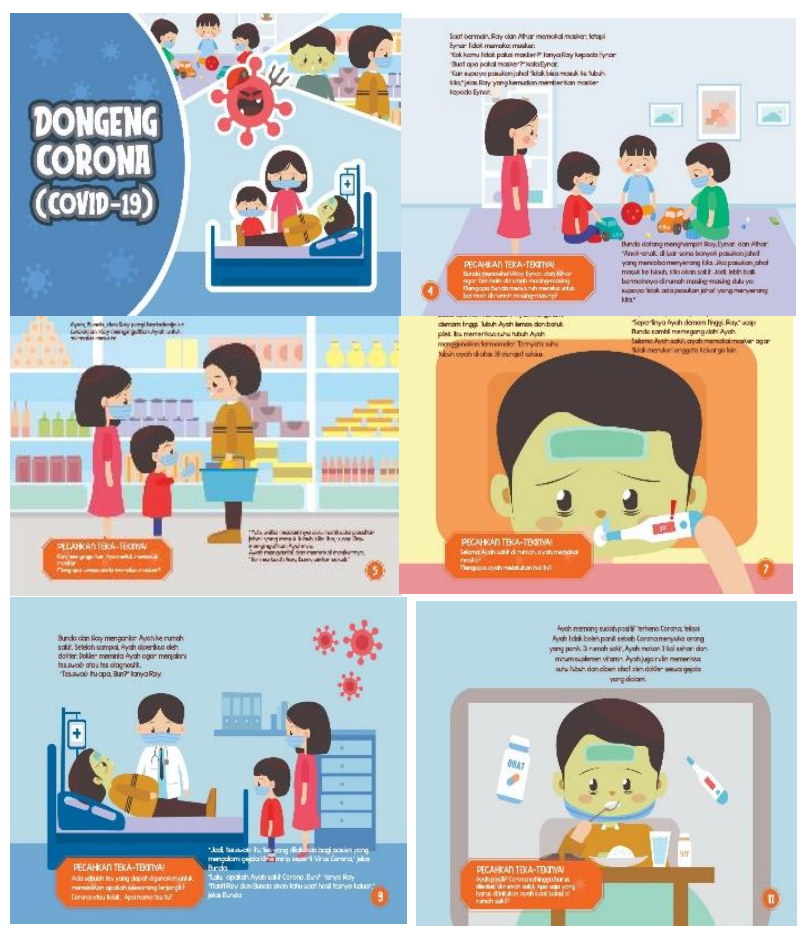

Figure 4. Covid-19 Fairytale Storyline

\subsection{Participant Response Questionnaire}

The response questionnaire comes from a questionnaire filled out by research subjects, namely children of elementary school age who have participated in research product trials. The results are shown in the following tables and figure.

\begin{tabular}{lcc}
\hline $\begin{array}{l}\text { In your opinion, is the Corona } \\
\text { Virus Dangerous? }\end{array}$ & $\begin{array}{l}\text { Sample } \\
\text { Number }\end{array}$ & $\begin{array}{l}\text { Percentage } \\
\text { Value }\end{array}$ \\
\hline Very Dangerous & 54 & $86 \%$ \\
\hline Dangerous & 9 & $14 \%$ \\
\hline Simply Dangerous & 0 & $0 \%$ \\
\hline Less Dangerous & 0 & $0 \%$ \\
\hline Not Harmful & 0 & $0 \%$ \\
\hline
\end{tabular}

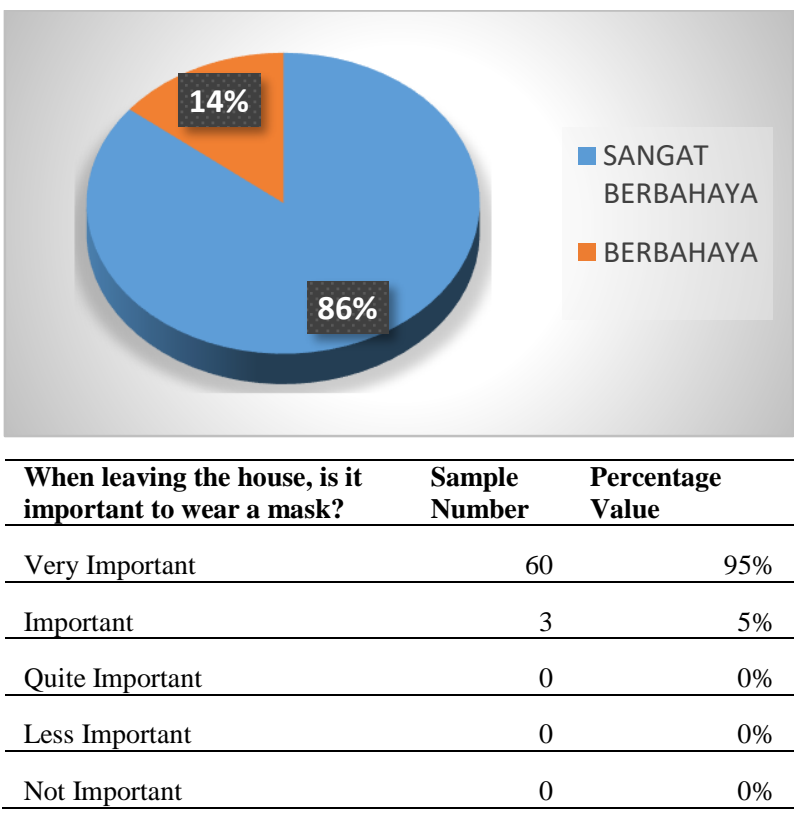

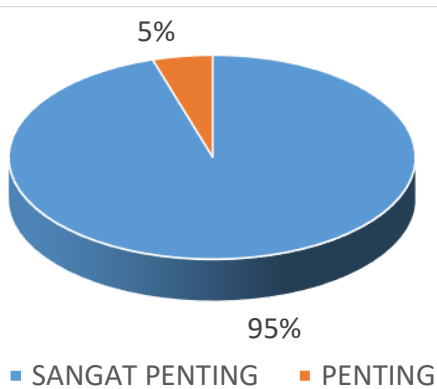

Figure 5 The Result of Questionnaire

From the questionnaire, it conclude that children who were the sample of research are aware for the dangerousnes of covid-19 and practice the habit of washing hands with soap, wearing masks, and maintaining distance before and after interacting with other people. 


\subsection{Expert Validation}

Expert validation is carried out by learning experts, media design experts, and teaching practitioners of fairy tale book media and fairy tale animation with the results shown in the following table.

Table 2. Expert Validation

\begin{tabular}{|c|c|c|c|}
\hline $\begin{array}{l}\text { VALIDATOR } \\
\text { FIELD }\end{array}$ & VALIDATION & DESCRIPTION & ADVICE \\
\hline $\begin{array}{l}\text { Elementary } \\
\text { Education }\end{array}$ & 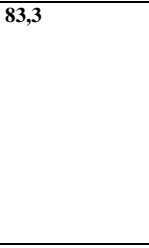 & $\begin{array}{l}\text { Worth using with a } \\
\text { little revision, the } \\
\text { material is quite } \\
\text { complete, quite } \\
\text { extensive and deep }\end{array}$ & $\begin{array}{l}\text { The book display and } \\
\text { illustrations are } \\
\text { attractive and suitable } \\
\text { for elementary school } \\
\text { children, and the } \\
\text { puzzles presented are } \\
\text { very contextual and } \\
\text { actual with daily } \\
\text { problems during the } \\
\text { COVID19 pandemic. }\end{array}$ \\
\hline DKV & 95 & $\begin{array}{l}\text { Worth using with a } \\
\text { little revision, the } \\
\text { material is quite } \\
\text { complete, quite } \\
\text { extensive and deep }\end{array}$ & $\begin{array}{l}\text { The paper thickness } \\
\text { for the cover (front and } \\
\text { back) needs to be } \\
\text { increased. It would be } \\
\text { ideal if the cover was } \\
\text { bound by hard cover } \\
\text { for reasons of } \\
\text { durability considering } \\
\text { that the target of this } \\
\text { book is children. }\end{array}$ \\
\hline $\begin{array}{l}\text { Elementary } \\
\text { School Teacher }\end{array}$ & 95 & $\begin{array}{l}\text { Worth using } \\
\text { without revision } \\
\text { because the } \\
\text { material is } \\
\text { complete, extensive } \\
\text { and deep. }\end{array}$ & $\begin{array}{l}\text { Increase the volume on } \\
\text { the video }\end{array}$ \\
\hline
\end{tabular}

Based on the results of expert validation, it shows that fairy tale books and animated fairy tale stories based on covid-19 are suitable for use with a little revision of the material with quite good depth and completeness of the material. The validation assessment given by learning experts, media experts, and learning practitioners to covid-19 based fairy tale books and animation are 83.3, 95 , and 95 respectively. Then, the average value is 91.1 which included very good category. Therefore, the books and the animation of Covid-19 fairytale suitable for dissemination phase to the other school or education institution for controlling the spread of covid-19.

\section{CONCLUSION}

Based on the results of the trial, it can be concluded that elementary school age children are able to understand the contents of fairy tales and carry out healthy living behaviors exemplified in fairy tales such as washing hands with soap before eating and after touching items or interacting with people, wearing masks when going out or when interacting with other people and maintain a safe distance when interacting with others.

Based on the results of expert validation, it shows that fairy tale books and animated fairy tale stories based on covid-19 are suitable for use with a little revision of the material with quite good depth and completeness of the material. The assessment given by learning experts, media experts, and learning practitioners to covid-19 based fairy tale books and animation is very good with an average value of 91.1. Therefore, the books and the animation of Covid-19 fairytale suitable for dissemination phase.

\section{ACKNOWLEDGMENTS}

This research is supported by the Universitas Negeri Surabaya as an university strategic policy research in order to accelerate the handling of the impact of Covid19.

\section{REFERENCES}

[1] Qin, Chuan, dkk. 2020. Dysregulation of Immune Response in Patients With Coronavirus 2019 (COVID-19) in Wuhan, China. Clinical Infectious Diseases, Volume 71, Issue 15, 1 August 2020, Pages 762-768.

[2] Schleifer, S. J., Keller, S. E., \& Bartlett, J. A. 1999. Depression and immunity: clinical factors and therapeutic course. Psychiatry Research Volume 85, Issue 1, 18 January 1999, Pages 63-69.

[3] Szabo, G. \& Mandrekar, P. 2009. A Recent Perspective on Alcohol, Immunity, and Host Defense. Alcoholism: Clinical \& Experimental Research Volume 33 Issue 2 pages 220-232.

[4] Putri, Gloria Setyvani. 2020. Kematian Anak Indonesia karena Corona Tertinggi di ASEAN, Ini Sebabnya.

https://www.kompas.com/sains/read/2020/06/04/17 0300423/kematian-anak-indonesia-karena-coronatertinggi-di-asean-ini-sebabnya?page=all. Retrieved August 9, 2020.

[5] Maharani, Esthi. 2020. Setiap Hari, Sekitar 100-200 Anak Positif Covid-19. https://republika.co.id/berita/qel8qw335/setiaphari-sekitar-100200-anak-positif-covid19. Retrieved August 9, 2020.

[6] -. 2020. Kelompok Umur Positif Covid-19. https://covid19.go.id/peta-sebaran. Retrieved August 9, 2020.

[7] Nugroho, A. S. \& Aminah, A. N. 2020. Tingkat Kematian Anak di Masa Covid-19 Kian Mengkhawatirkan.

https://republika.co.id/berita/qcgxxy384/tingkatkematian-anak-di-masa-covid19-kianmengkhawatirkan. Retrieved August 9, 2020.

[8] Brodin, Petter. 2020. Why is COVID - 19 so mild in children? Acta Paediatrica, Wiley Online Library.

[9] Akpan, J. P., \& Beard, L. A. (2016). Using constructivist teaching strategies to enhance academic outcomes of students with special needs. Universal Journal of Educational Research , 392398.

[10] Istiana, Purwani. 2016. Gaya Belajar dan Perilaku Digital Native terhadap Teknologi Digital dan 
Perpustakaan. Proceeding Seminar Nasional SLIMS

Commeet West Java, Bandung.

[11]DePorter, Bobbi dan Hernacki, Mike. 2013. Quantum Learning: Membiasakan Belajar Nyaman dan Menyenangkan. Bandung: Kaifa Learning.

[12]Juanda. 2018. Revitalisasi Nilai Dalam Dongeng Sebagai Wahana Pembentukan Karakter Anak Usia Dini. Jurnal Pustaka Budaya. Vol. 5, No. 2, Juli 2018.

[13] Tang, Yi-Wei. et al. 2020. Laboratory Diagnosis of COVID-19: Current Issues and Challenges. Journal of Clinical Microbiology Volume 58 Issue 6.

[14]Wojciechowski, A. \& Palmer, L.B. 2005. Individual Student Characteristics: Can Any Be Predictors of Success In Online Classes?. Online Journal of Distance Learning, VIII, 2005.

[15] Nurgiyantoro, Burhan. 2013. Sastra Anak Pengantar Pemahaman Dunia Anak. Yogyakarta: Gadjah Mada University Press.

[16]Tarigan, Henry Guntur. 2011. Dasar-Dasar Psikosastra. Bandung: Angkasa.G. Aston, "Surgical Robots Worth the Investment," 2012. [Online]. Available: http://www.hhnmag.com/.

[17]Sumantri, J. S. 1999. Filsafat Ilmu, Jakarta Pustaka Sinar Harapan.

[18]Darmawan, Handy. 2016. Pembelajaran Berbasis Konstruktivisme Menggunakan Media Animasi dengan Kerangka Kerja TPCK dan Gaya Belajar terhadap Prestasi Belajar Siswa. Jurnal Formatif 6(1), pages 1-11, 2016.

[19] Nurani, R. Z., Nugraha, F., dan Sidik, G. S. 2018. Penggunaan Media Audio Visual dalam Pembelajaran Menyimak Dongeng di Era Digital. EduHumaniora: Jurnal Pendidikan Dasar, Vol. 10 No.2, Hlm. 78-84, Juli 2018.

[20] Setia, L. D. dan Khudori, A. 2019. Penerapan Aplikasi Multimedia Interaktif Pembelajaran Membaca Metode Suku Kata dan Digital Media Dongeng Karakter. Prosiding Seminar Nasional Teknologi Informasi dan Komunikasi 2019 pages 161-164.

[21] Purwati, Yuli, dkk. 2020. Windows Communication Foundation untuk Audiobook Dongeng bagi Anak Penyandang Tunanetra. Jurnal Teknologi Informasi dan Ilmu Komputer (JTIIK) Vol. 7, No. 2, April 2020, pages 339-348.

[22] Sugiyono. 2015. Metode Penelitian Pendidikan, Pendekatan Kuantitatif, Kualitatif, dan R\&D. Bandung: Alfabeta. 